University of Arkansas, Fayetteville

ScholarWorks@UARK

Education Reform Faculty and Graduate

Students Publications

Education Reform

4-8-2019

\title{
Assessing the Impact of Holocaust Education on Adolescents' Civic Values: Experimental Evidence from Arkansas
}

\author{
Mathew Lee \\ University of Arkansas, Fayetteville \\ Molly I. Beck \\ University of Arkansas, Fayetteville
}

Follow this and additional works at: https://scholarworks.uark.edu/edrepub

Part of the Educational Assessment, Evaluation, and Research Commons, Educational Leadership Commons, Holocaust and Genocide Studies Commons, and the Other Educational Administration and Supervision Commons

\section{Citation}

Lee, M., \& Beck, M. I. (2019). Assessing the Impact of Holocaust Education on Adolescents' Civic Values: Experimental Evidence from Arkansas. Education Reform Faculty and Graduate Students Publications. Retrieved from https://scholarworks.uark.edu/edrepub/75

This Article is brought to you for free and open access by the Education Reform at ScholarWorks@UARK. It has been accepted for inclusion in Education Reform Faculty and Graduate Students Publications by an authorized administrator of ScholarWorks@UARK. For more information, please contact scholar@uark.edu. 


\title{
WORKING PAPER SERIES
}

\author{
Assessing the Impact of Holocaust Education on Adolescents' Civic Values: \\ Experimental Evidence from Arkansas
}

Matthew H. Lee and Molly I. Beck

March 25, 2019

EDRE Working Paper 2019-08

The University of Arkansas, Department of Education Reform (EDRE) working paper series is intended to widely disseminate and make easily accessible the results of EDRE faculty and students' latest findings. The Working Papers in this series have not undergone peer review or been edited by the University of Arkansas. The working papers are widely available, to encourage discussion and input from the research community before publication in a formal, peer reviewed journal. Unless otherwise indicated, working papers can be cited without permission of the author so long as the source is clearly referred to as an EDRE working paper. 


\title{
char·asse.in \\ THE CHARACTER ASSESSMENT INITIATIVE
}

\section{Assessing the Impact of Holocaust Education on Adolescents' Civic Values: \\ Experimental Evidence from Arkansas}

\author{
Matthew H. Lee* \\ University of Arkansas
}

Molly I. Beck

University of Arkansas

This Version: March 2019

\footnotetext{
* Corresponding author. Address 212 Graduate Education Building, Fayetteville, Arkansas, 72701;

Tel.:1-479-575-6345; E-mail address: mhl002@uark.edu
} 


\begin{abstract}
American adults overwhelmingly agree that the Holocaust should be taught in schools, yet few studies investigate the potential benefits of Holocaust education. We evaluate the impact of Holocaust education on several civic outcomes, including “upstander" efficacy (willingness to intervene on behalf of others), likelihood of exercising civil disobedience, empathy for the suffering of others, and tolerance of others with different values and lifestyles. We recruit students from two local high schools and randomize access to the Arkansas Holocaust Education Conference, where students have the chance to hear from a Holocaust survivor and to participate in breakout sessions with leading Holocaust experts. We find that students randomly assigned to attend the conference become more knowledgeable about the Holocaust and are more willing to act as an upstander on behalf of others. In our subgroup analysis, we find that minority students are significantly more willing to act as an upstander relative to their white peers.

Keywords: civics, tolerance, empathy, Holocaust, field trips, social studies, upstander efficacy
\end{abstract}


Assessing the Impact of Holocaust Education on Adolescents' Civic Values:

Experimental Evidence from Arkansas

The things I saw beggar description... The visual evidence and the verbal testimony of starvation, cruelty and bestiality were so overpowering... I made the visit deliberately, in order to be in a position to give first-hand evidence of these things if ever, in the future, there develops a tendency to charge these allegations to propaganda.

—Dwight D. Eisenhower, April 15, 1945

Upon liberating the concentration camp near Ohrdruf, Germany and witnessing evidence

of the horrifying crimes the Nazis committed, General Dwight D. Eisenhower, Supreme

Commander of the Allied Forces, immediately resolved to preserve a record of these crimes for

fear they would be considered too unbelievable to have taken place. The crimes in question refer

to the Holocaust, a part of the Final Solution to the Jewish Question in which the Nazis

systematically exterminated an estimated 17 million victims, including six million Jews and

several hundred thousand Romani (Gypsies), homosexuals, patients with mental and physical

disabilities, and others the Nazis deemed "subhuman." Many of these killings took place in

dedicated extermination camps such as Auschwitz-Birkenau and Treblinka, spread across

Germany, Poland, Czechoslovakia, and other occupied territories. The Holocaust, often referred

to as the shoah, the Hebrew word for "destruction," is considered by many to be one of the

greatest tragedies of modern human history (Crowe, 1970; Gilbert, 1987; Landau, 1992; Dwork

\& Van Pelt, 2002; Longerich, 2010; etc.).

Seven decades after the events of the Holocaust, American adults overwhelmingly agree

that the Holocaust is an important period of modern history to study yet demonstrate limited

knowledge of its events. Researchers from Schoen Consulting, a private research firm,

conducted a nationally-representative survey of Holocaust knowledge and awareness and found

that $93 \%$ of all US adults "believe all students should learn about the Holocaust in school"

(Schoen Consulting, 2018, p. 6). This response may be partly explained by the fact that $80 \%$ of 
surveyed adults indicate that teaching about the Holocaust was important to prevent a similar genocide from reoccurring, and 58\% felt that an atrocity or crime against humanity like the Holocaust could happen again (Schoen Consulting, 2018). Despite this strong sense of the subject's importance, the study finds "significant gaps in knowledge of the Holocaust," including awareness of the Holocaust, the number of Jews killed in the Holocaust, the countries in which the Holocaust occurred, and the ability to name or identify specific concentration camps (Schoen Consulting, 2018, p. 2).

The survey's troubling findings were widely reported in popular news media. Alan Marcus, associate professor at the University of Connecticut's Neag School of Education argues that expanded Holocaust education has the potential to "create a better society" as students of the Holocaust would "need to grapple with complicated moral issues" (2018, p. 1). Connecticut state legislators followed this rationale to mandate Holocaust education "as a way of dealing with the increase in hate crimes" (Marcus, 2018, p. 1). Greg Schneider, the executive vice president of the Conference on Jewish Material Claims Against Germany, expresses concern that the Holocaust is "receding from memory" (Astor, 2018). As survivors and others with personal connections to the Holocaust continue to advance in age, museums and memorials around the world are "looking for ways to tell the witnesses' stories once the witnesses are gone" (Astor, 2018, p. 1).

Despite these concerns, as of 2017 only eight states (New York, New Jersey, Florida, Illinois, California, Rhode Island, Michigan, and Indiana) require some form of Holocaust education (Ziv, 2017). Connecticut and Kentucky passed mandates in 2018 and Pennsylvania strongly encourages but does not require such instruction. Representatives in 20 other states have pledged to pass similar legislation (Marcus, 2018; Ziv, 2017). 


\section{Literature Review}

Education researchers and curriculum experts conjecture that studying the Holocaust imparts essential lessons of civic values, including justice, tolerance, and the importance of democratic liberties (Doering \& Pekarik, 1996; Carrington \& Short, 1997; Shiman \& Fernekes, 1999; Russell, 2005; Lindquist, 2006). Russell (2005) argues that teaching about the Holocaust "helps students develop an awareness of the value of pluralism and encourages tolerance of diversity in a pluralistic society" (p. 93). Unfortunately, it remains unclear how Holocaust education programming affects the students who experience it (Brabham, 1997; Totten, 2012). The existing literature examines, mainly by case studies, the effects of Holocaust education through two different delivery modes - (1) Holocaust education in the classroom, led primarily by a teacher, and (2) Holocaust education outside the classroom, such as visiting a Holocaust museum or a memorial site.

\section{Holocaust education inside the classroom}

The majority of scholarly work looking at the effects of Holocaust educational programming in the classroom, such as reading a Holocaust-related book or receiving instruction on the Holocaust, examines the association between Holocaust education and civic outcomes. For example, Carrington and Short (1997) provide a case study of 43 students between ages 14 and 15 in the United Kingdom, asking them through semi-structured interviews whether or not their study of the Holocaust in the previous year had affected their "notions of citizenship ... [and] understanding of human rights issues" (p. 273). The authors find that for the students involved, Holocaust education is associated with greater preparation for active citizenship and greater understanding of racism, but cautioned that educators may need to combat against 
complacency; several students were not worried that events like those of the Holocaust could happen again because of watchdog agencies (Carrington \& Short, 1997, p. 280).

Other descriptive longitudinal studies find evidence suggesting possible benefits of Holocaust education on civic outcomes. Cowan and Maitles (2005) found that, in the short term, Holocaust education was associated with an increase in self-reported tolerance for minority groups among Scottish children. In the long-term follow-up to their previous work, Cowan and Maitles find that attitudes about tolerance remain higher for students who received Holocaust education (2007). They also find that, in comparison to a group of students who did not receive Holocaust education, those students also felt a greater sense of "collective responsibility" for working against racist attitudes, being less likely to agree with the statement "I think racism has nothing to do with me" (Cowan \& Maitles, 2007, p. 126). In the United States, Starratt, Fedotovic, Goodletty, and Starratt (2017) find that studying the Holocaust in the classroom is moderately correlated with what they broadly consider "citizenship values" in American adults later in life.

Apart from questions of methodological rigor, one of the concerns with the research into teaching the Holocaust in the classroom is that teachers seem to encounter pedagogical "pitfalls" (Lipstadt, 1995, p. 27) when implementing Holocaust education programs in the classroom. For example, several researchers note concerns that Holocaust education may be narrow or shallow, failing to establish the broad historical context in which the Holocaust took place (Schweber, 2003; Lindquist, 2006; Riley \& Totten, 2002; Wieser, 2001). Lipstadt (1995) notes that teachers often lead students to make inappropriate comparisons to other human rights topics in history such as the passage of Jim Crow laws or the internment of Japanese-Americans, in which groups faced intense persecution and discrimination, but were not killed on a scale comparable to the 
Holocaust. Finally, Riley \& Totten (2002) express the concern that teachers may sometimes convey inaccurate information to students.

\section{Holocaust education outside the classroom}

Beyond classroom instruction, students experience Holocaust educational programming through visits to memorial sites where horrific events of the Holocaust took place or to museums dedicated to chronicling the events of the Holocaust and commemorating its victims. In contrast to in-class educational programming, few studies analyze how visits to museums and memorial sites affects students' knowledge of the Holocaust or civic values; the work that exists suggests null to mildly positive impacts. For example, researchers evaluating educational trips to Yad Vashem, the Holocaust memorial and museum in Jerusalem, find that the visit to the museum did not affect knowledge of the Holocaust and produced only a minimal effect in reducing anxiety when reflecting on the Holocaust for Israeli teens (Bickman \& Hamner, 1998). An experimental evaluation of three different types of educational programing at the United States Holocaust Memorial Museum in Washington, D.C. did not find differential effects on students' knowledge and mixed results on students' attitudes across the three types of programs (Downey, 2000). It should be noted that Downey's evaluation did not have a true control group, as all groups visited the Permanent Exhibition, but were randomly assigned to additional programming - a combination of the teacher guide, orientation program, and/or follow-up session. Finally, in a recent experimental study, researchers brought middle and high school students to the Holocaust Museum Houston and find that the experience strengthened students' commitment to protect civil liberties and improved their knowledge of the Holocaust, but surprisingly reduced their levels of religious tolerance (Bowen \& Kisida, 2018). 


\section{The future of civics education?}

In addition to providing important historical information about the genocide the Nazis perpetrated against the Jews and other minority groups, Holocaust education could play an important role in providing general civics education for students, which will help them participate in a larger and more diverse community. Since the days of Horace Mann's common school, education scholars broadly agree that education serves not only to train the minds of students, but also to prepare them in civics to become active and engaged citizens in a democratic society (Gutmann, 1987; Hirsch, 2009; Peterson, 2010; Levinson, 2012). Today, most states require a civics course, though only nine states and the District of Columbia require a full year of civics education and only 17 states require passing a civics exam to graduate from high school (Shapiro \& Brown, 2018). An investigation into how social studies teachers promote citizenship finds that public and private school teachers agree on the priorities of teaching citizenship, but at the same time "appear uncertain about what the precise content of a proper civic education should be" (Hess, Schmitt, Miller, \& Schuette, 2010, p. 1). Unfortunately, there is a growing concern that accountability testing has made social studies and civics an afterthought (West, 2007; Farkas \& Duffett, 2010; Brown, 2015)

We make a valuable contribution to the literature through an experimental evaluation of the $27^{\text {th }}$ annual Arkansas Holocaust Education Conference, held on November $16^{\text {th }}, 2018$ at the Jones Center for Families in Springdale, AR. To our knowledge, this experimental evaluation of a Holocaust intervention is the first involving a Holocaust survivor.

The theme of this year's conference was “The Holocaust: What Was It? Who Knew? Who Cared?" We recruited 105 high school students from a large district public school and a 
small public charter school and randomly assigned 50 students to have access to the conference, which featured as its keynote speaker Pieter Kohnstam, a Holocaust survivor and the author of $A$ Chance to Live. Dr. Kevin Simpson, professor of psychology at John Brown University, delivered a separate address in which he connected the Holocaust to current events, including the recent Tree of Life synagogue shooting in Pittsburgh, PA on October 27, 2018 and the separation of migrant families at the U.S.-Mexico border in late 2018. In addition to the two addresses, students had the opportunity to attend three of seven concurrent sessions held throughout the day. These sessions were led by various Holocaust experts, including university professors, lecturers, and Holocaust Museum Fellows. A summary of available breakout sessions can be found in Appendix A1.

\section{Theoretical Framework}

Considering the previous literature, we hypothesize that students randomly assigned to attend the Holocaust Education Conference might become more knowledgeable about the Holocaust and more likely to report desirable civic attitudes. We theorize that the mechanisms for this change come from the following components:

1. Exposure to information will lead to an increase in knowledge in a given subject. Exposure to information presented in a salient manner or in an intense setting will make an even greater impression.

2. Knowledge about a period of history in which civic values or attitudes were tested will cultivate or fortify those values and attitudes.

3. An education intervention designed to increase knowledge will be more effective for students with less knowledge about a given period of history, students who 
believe a period of history is important to study, or students who may be able to sympathize with the groups or individuals involved in that period of history.

\section{Exposure to information will lead to an increase in knowledge}

Descriptive longitudinal studies of Holocaust education in the classroom raise concerns about how the Holocaust is taught. These concerns include failing to place the Holocaust in its proper historical context (Lindquist, 2006; Russell, 2005; Totten, Holocaust education, 2012; Foster, et al., 2016), making inappropriate comparisons to other periods of history (Lipstadt, 1995), and including inaccuracies in content (Riley \& Totten, 2002). An intervention such as the conference we evaluate, which features university professors, certified Holocaust museum fellows, and other experts in the field, should alleviate these concerns about Holocaust education. Prior research demonstrates that experiential learning can be effective at improving knowledge and critical thinking skills. Such experiential learning can include visiting art museums (Bowen, Greene, \& Kisida, 2014; Greene, Kisida, \& Bowen, 2014; Kisida, Bowen, \& Greene, 2016), visiting science educational institutions (Weinstein, Whitesell, \& Schwartz, 2014; Whitesell, 2016), and viewing live theater (Greene, Erickson, Watson, \& Beck, 2018). We theorize that hearing from a Holocaust survivor or expert may have a more meaningful impact on students than receiving instruction from someone with no personal connection to or expertise in the Holocaust.

\section{Knowledge about history can cultivate civic values and attitudes}

The study of the Holocaust may help to cultivate civic values and attitudes. Just as teachers are unsure how to approach teaching the Holocaust, there are similar uncertainties about 
teaching civics (Hess, Schmitt, Miller, \& Schuette, 2010). Totten (2013) speculates that including controversial issues in the classroom can improve reflective thinking. Holocaust education particularly can help instill these civic values in students as they wrestle with difficult moral questions (Landau, 1992; Carrington \& Short, 1997). U.S. state legislators have proposed it as a means of reducing hate crimes (Ziv, 2017; Astor, 2018; Marcus, 2018). Descriptive longitudinal studies of Holocaust education find it to be associated with students' reduced racist perceptions of minority groups (Cowan \& Maitles, 2005; 2007) and positively associated with students' democratic and civic values (Carrington \& Short, 1997; Starratt, Fredotovic, Goodletty, \& Starratt, 2017). Others theorize that learning about the Holocaust can improve altruism (Tec, 1995), empathy (Jennings, 2010), and commitment (Shiman \& Fernekes, 1999).

Unfortunately, experimental evaluations of Holocaust education programming do not find that Holocaust education realizes these theoretical expectations. Bickman and Hamner (1998) find some benefits of visiting Yad Vashem, as students randomly assigned to visit the museum became less anxious about reflecting on the Holocaust and became less likely to agree that Jewish identity was weakened because of the Holocaust. Downey (2000) finds that students who visited the Permanent Exhibit and were randomly assigned to one of three additional forms of education programming at the U.S. Holocaust Memorial Museum felt more engaged with history, but felt less strongly that the Holocaust was personally relevant to them. Finally, Bowen and Kisida (2018) find that students randomly assigned to attend the Holocaust Museum Houston were more likely to prefer civil liberties over order but reported lower levels of religious tolerance. Thus, experimental evaluations of Holocaust educational programming do not consistently find it to fortify students' civic values. 
We theorize that improved knowledge about the Holocaust will strengthen in students the civic values that were tested during the Holocaust: willingness to serve as an upstander on behalf of others (that is, to intervene on behalf of others), proclivity to civil disobedience, empathy for the suffering of others, and tolerance of others with different values or lifestyles. These values are immediately relevant to the students in their respective school communities and will continue to be relevant to them as they enter into adulthood and begin participating in a democratic society.

\section{An intervention can be more or less effective for subgroups of students}

Broadly speaking, studies find that experiential learning can be beneficial for historically underserved student groups (Greene, Kisida, \& Bowen, 2014; Kisida, Bowen, \& Greene, 2016; Whitesell, 2016). Experimental evaluations of Holocaust education interventions provide some evidence that Holocaust education can be more or less effective for subgroups of students. Bickman and Hamner (1998) fail to detect a significant effect of being randomly assigned to visit Yad Vashem on students' knowledge of the Holocaust; however, their student population was composed of Israeli youths, many of whom had met a Holocaust survivor, had a relative who died in the Holocaust, or had already read a book about the Holocaust. In contrast, Arkansas students may not be as knowledgeable about the Holocaust, as the Arkansas state social studies standards do not mandate the teaching of the Holocaust.

Although Downey (2000) fails to detect an effect on knowledge, she notes some heterogeneity of effect estimates, as having greater interest and prior academic preparation contributed to a student's level of Holocaust knowledge. Finally, Bowen and Kisida (2018) find 
that effects on both knowledge and civic attitudes varied across gender, race, and parents' level of education.

\section{Methodology}

\section{Data}

Working with administrators and teachers from a large district public school and a small public charter school, we recruited 105 students for this project. The Arkansas Holocaust Education Committee set aside 50 conference seats for our use, allowing us to randomly assign students to treatment and control groups by lottery. We simulated 100 randomizations stratifying at the school level and chose the simulation with the best balance on baseline characteristics. Baseline survey measures were collected prior to randomization and were used to test treatment and control groups for balance. These descriptive characteristics are summarized in Tables 1-4.

[Table 1 about here]

[Table 2 about here]

[Table 3 about here]

We merge together administrative data from both schools with surveys the students completed before and after the intervention. The survey includes questions that test knowledge of the Holocaust and a number of self-reported measures of civic outcomes. These outcomes include willingness to be an upstander $(\alpha=0.79)$, likelihood of exercising civil disobedience $(\alpha=$ $0.85)$, empathy for the suffering of others $(\alpha=0.92)$, and tolerance of others with a different religious background, political perspective, racial background, and sexual orientation $(\alpha=0.93)$. To capture exposure to Holocaust materials prior to the conference, we asked students to report whether or not they had read or seen any of eight Holocaust-related books or movies and to 
recall the number of class periods they had received with instruction on the Holocaust. Finally, we surveyed students on how interested they were in the study of history generally and of the Holocaust particularly. Treatment and control groups demonstrated balance on all baseline measures with two exceptions. While the two groups are balanced on the overall construct of exposure to the Holocaust as a subject, a greater proportion of treatment group students had read Night by Elie Wiesel $(p<0.10)$ and a smaller proportion of treatment group students had seen the film Life is Beautiful $(p<0.10)$. A summary of survey measures can be found in Tables 5-6. Survey measures are either taken directly or adapted closely from prior evaluations of students' attitudes and values by Spreng, McKinnon, Mar, and Levine (2009), Gibson and Bingham (1982), Graham, Haidt, and Nosek (2009), Slaby, Wilson-Brewer, and Devos (1994), Banyard, Moynihan, and Plante (2007), and Bowen and Kisida (2018). A number of survey measures are reverse-coded in an effort to ensure survey fidelity.

[Table 4 about here]

[Table 5 about here]

[Table 6 about here]

\section{Analytical Strategy}

We use the following models in order to estimate the effect of being randomly assigned to attend the Arkansas Holocaust Education Conference on various student outcomes:

1. $Y_{i t}=\beta_{0}+\beta_{1}$ treat $_{i}+\delta_{s}+\epsilon_{i}$

2. $Y_{i t}=\beta_{0}+\beta_{1}$ treat $_{i}+\boldsymbol{X}_{i} \beta+\delta_{s}+\epsilon_{i}$

3. $Y_{i t}=\beta_{0}+\beta_{1}$ treat $_{i}+\beta_{2} Y_{i t-1}+\boldsymbol{X}_{i} \beta+\delta_{s}+\epsilon_{i}$

4. $Y_{i t}=\beta_{0}+\beta_{1}$ treat $_{i}+\beta_{2}$ treat $_{i} *$ subgroup $_{i}+\beta_{3} Y_{i t-1}+\boldsymbol{X}_{i} \beta+\delta_{s}+\epsilon_{i}$ 
where:

- $Y_{i t}$ represents our post-treatment outcomes of interest;

- treat $_{i}$ is student $i$ 's randomly-assigned treatment status and $=1$ for treatment and $=0$ for control;

- $\boldsymbol{X}_{i}$ is a vector of time-invariant student characteristics, including gender, age, and race;

- $\delta_{s}$ is the school fixed-effect; and

- $\epsilon_{i}$ is the individual's error term.

In our simple model (1), we regress each outcome only on each student $i$ 's treatment status. We control for a vector of time-invariant student characteristics from administrative data, including the student's gender, age, and race in model (2). In our preferred model (3), we also control for the student's corresponding pre-treatment survey measure. Finally, for our subgroup analysis in model (4), we add an interaction term treat ${ }_{i} * \operatorname{subgroup}_{i}$ for our subgroup analysis, according to the student's race (white or minority) or gender (male or female). Our coefficient of interest is $\beta_{1}$, which captures the effect of being randomly assigned to attend the Holocaust conference on student outcomes. We include a school fixed effect and cluster our standard errors at the classroom level in all our models.

We cluster our standard errors at the classroom level for a number of reasons. The most obvious reason is the computational advantage of having the greatest number of clusters of smallest size. Furthermore, clustering standard errors at the classroom level should capture the most meaningful correlation among error terms for our study, as correlated errors at higher aggregate levels would in theory have minimal influence on our outcomes. 


\section{Results}

\section{Main Findings}

Of the 50 students assigned to attend the conference, 39 students attended the conference, a compliance rate of $78 \%$. Our sample suffered no control-treatment crossovers as none of the 55 students assigned to the control group attended the conference. Of the 105 total students in our sample, 103 students (50 treatment, 53 control) completed pre-intervention surveys and 102 students (49 treatment, 53 control) completed post-intervention surveys.

[Table 7 about here]

We find that students randomly assigned to attend the Arkansas Holocaust Education Conference became more knowledgeable about the Holocaust and reported greater upstander efficacy after the intervention. Students in the treatment group on average correctly answered 7.59 out of 10 questions about the Holocaust. Students in the control group on average correctly answered 7.34 questions. Controlling for student demographics and baseline knowledge, being randomly assigned to attend the conference improves knowledge by 0.26 standard deviations, an effect that is statistically significant at the $90 \%$ confidence level $(p=0.06)$. We also detect an effect on willingness to serve as an upstander. Treatment group students expressed a greater willingness to act as an upstander on behalf of others, a difference of 0.27 standard deviations holding all else equal, an effect that was statistically significant at the $90 \%$ confidence level $(p<$ 0.10). We find suggestive evidence that treatment groups were more empathetic $(0.21$ standard deviations), but fail to reject the null hypothesis that they experienced no effect on their selfreported empathy $(p=0.12)$. Our main findings are summarized in Table 7 .

[Figure 1 about here]

[Figure 2 about here] 


\section{Subgroup Analysis}

Finally, we conduct subgroup analysis across race and gender by introducing an interaction term into our preferred model. These findings are summarized in Table 9, where the left three columns represent our analysis across race and the right three columns represent our analysis across gender. At baseline, we detect no statistically significant differences across treatment and control groups within student subgroup categories (see Table 8).

[Table 8 about here]

For our analysis across race, the first column captures the effect of being randomly assigned to attend the conference for white students, the second column captures the effect of being randomly assigned to attend the conference for minority students, and the third column captures the difference between subgroups, the interaction term. First, we see that the main effect we detect on students' knowledge of the Holocaust is primarily driven by minority students. Minority students in the treatment group became more knowledgeable than their control group peers by almost half a standard deviation. This effect was statistically significant at the $90 \%$ confidence level. Although white students in the treatment group scored almost a fifth of a standard deviation higher than their control group peers on questions testing knowledge, the difference was not statistically significant and therefore we cannot rule out the possibility that the conference did not improve their knowledge of the Holocaust $(p>0.10)$.

[Table 9 about here]

We detect a differential effect on students' willingness to serve as an upstander. Minority students in the treatment group became more willing to serve as an upstander by almost threequarters of a standard deviation relative to their control group peers, a difference that was 
significant at the $99 \%$ confidence level. In contrast, we fail to detect a statistically significant difference for white students in the treatment group relative to their control group counterparts. The difference between minority students and white students in the treatment group, almost seven-tenths of a standard deviation, is also statistically significant $(p<0.05)$.

For our analysis across gender, the fourth column represents the effect of being randomly assigned to attend the conference for male students, the second column captures the effect of being randomly assigned to attend the conference for female students, and the third column captures the difference between subgroups, the interaction term. We detect no statistically significant effects on either the male or female subgroup and we detect no statistically significant difference between the male and female subgroups on any of our tested outcomes.

[Figure 3 about here]

\section{Sensitivity Checks}

To test the sensitivity of our effect estimates to additional control variables, we add to our preferred model controls for baseline knowledge, interest, and exposure to Holocaust-themed books and movies. Our rationale for controlling for these measures comes from Downey (2000), who notes that students with greater interest and prior academic preparation before visiting the U.S. Holocaust Memorial Museum demonstrated higher levels of Holocaust knowledge. For baseline interest, we control for how strongly students agreed with the following two statements: (1) I am interested in learning more about the Holocaust; and (2) Learning about the Holocaust can help prevent further violence. Finally, we add all of these controls into our final model, reported in Table 10, Column 5. 
Overall, we find that our effect estimates are not very sensitive to the inclusion or exclusion of these controls with only three exceptions. Effect estimates that were not statistically significant in our preferred model remain statistically insignificant across our sensitivity checks. Effect estimates for upstander efficacy range from 0.27 to 0.29 standard deviations and remain significant at the $90 \%$ confidence level, with the exception of the model in which we include all controls, when the effect estimate rises to 0.30 standard deviations and is statistically significant at the $95 \%$ confidence level. The effect estimate for knowledge rises to 0.27 standard deviations when controlling for baseline exposure, but remains statistically significant at the $90 \%$ confidence level. However, when controlling for baseline interest or including all controls, the effect estimate for knowledge rises to 0.28 standard deviations and is statistically significant at the $95 \%$ confidence level.

Our sensitivity checks strengthen our confidence in the effect estimates we detect on upstander efficacy and knowledge. Our hope is that future replications will give us greater clarity as to the true relationship between Holocaust education and these constructs.

[Table 10 about here]

\section{Discussion}

Our findings are reasonable, especially when considering the theme of this year's conference: “The Holocaust: What Was It? Who Knew? Who Cared?" The effect on knowledge is primarily driven by the treatment group's ability to correctly identify that Germans beyond Hitler and high-ranking Nazi officials knew about and carried out the Holocaust (see Table 8). This concept was the subject of three of the seven breakout sessions students could have attended ("Undeniable Proofs" by Chad Austin, "What They Knew and When They Knew It" by Lance 
Jones, and "What Germans Knew About the Holocaust" by Laura Prichard Dobrin; see Appendix A1 for more details).

This knowledge was directly connected to the willingness of outsiders to intervene on behalf of the suffering of others. In his opening address, Dr. Kevin Simpson drew parallels between the Holocaust and recent events, including the Tree of Life synagogue shooting and the separation of migrant families on the U.S.-Mexico border. Furthermore, two of the seven breakout sessions dealt with the response of Americans to the Holocaust during the 1940s ("When Lady Liberty Snuffed Out Her Welcome Lamp" by Sol Factor and "The American Public and The Holocaust" by Jacqueline Littlefield). Together with one of the themes of the conference, "Who Cared?", these sessions may account for the effect we detect on upstander as well as the suggestive evidence of a positive association with empathy. The fact that each Holocaust educational intervention can emphasize a different theme may explain the inconsistent findings across these prior experimental studies, which have been null (Bickman \& Hamner, 1998; Downey, 2000) or positive (Bowen \& Kisida, 2018) on student knowledge, and positive (Bickman \& Hamner, 1998; Bowen \& Kisida, 2018), null (Downey, 2000), or negative (Bowen \& Kisida, 2018) on various student attitudes.

[Table 11 about here]

Although the theme and topics of this year's Arkansas Holocaust Education Conference may account for the particular effects detected, the conference exhibits several characteristics that remain consistent across all previous years, and we believe will continue through future events. For example, a Holocaust survivor often delivers the keynote address, and though the theme changes from year to year, subject-matter experts lead breakout sessions. These conference fixtures may address the pedagogical "pitfalls" (Lipstadt, 1995, p. 27) which may 
ensnare in-class Holocaust educational programming as attendees receive accurate content knowledge that is situated in its historical context. Thus, we anticipate that replicating this study in future years will provide greater clarity of the true nature of the potential benefits of Holocaust education on adolescents' knowledge and civic values.

\section{Conclusion}

We find some evidence that Holocaust education programming is beneficial for students. In our study, students randomly assigned to attend the conference became more knowledgeable (0.26 standard deviations, $p=0.06)$ and expressed greater willingness to serve as an upstander (0.27 standard deviations, $p<0.10)$. Both effects were significant at the $90 \%$ confidence level. In our subgroup analysis, we find that minority students randomly assigned to attend the conference report being more willing to serve as an upstander ( 0.72 standard deviations, $p<$ $0.01)$ and they were more willing to do so relative to their white peers ( 0.63 standard deviations, $p<0.05)$. Minority students randomly assigned to attend the conference also became more knowledgeable $(0.48$ standard deviations, $p<0.10)$, but the difference relative to their white peers was not statistically significant at conventional levels. Many of our effect estimates on other outcomes are economically substantial, but statistically insignificant. Replication of this study in future years will help us gain more clarity as to the true nature of the benefits of Holocaust education for high school students. 


\section{References}

Astor, M. (2018, April 12). Holocaust is fading from memory, survey finds. New York Times. Retrieved from https://www.nytimes.com/2018/04/12/us/holocaust-education.html

Banyard, V. L., Moynihan, M. M., \& Plante, E. G. (2007). Sexual violence prevention through bystander education: An experimental evaluation. Journal of Community Psychology, 35(4), 463-481.

Bickman, L., \& Hamner, K. M. (1998). An evaluation of the Yad Vashem Holocaust Museum. Evaluation Review, 22(4), 435-446.

Bowen, D. H., Greene, J. P., \& Kisida, B. (2014). Learning to think critically: A visual art experiment. Educational Researcher, 43(1), 37-44.

Bowen, D., \& Kisida, B. (2018, April). An experimental investigation of the Holocaust educational impacts on students' civic attitudes and behaviors. Paper presented the meeting of the American Educational Research Association, New York City, NY.

Brabham, E. G. (1997). Holocaust education: Legislation, practices, and literature for middleschool students. The Social Studies, 88(3), 139-142. doi:10.1080/00377999709603761

Brown, J. B. (2015, April 29). Eighth graders' flatline on NAEP U.S. history, civics, and geography tests. Education Week. Retrieved from http://blogs.edweek.org/edweek/curriculum/2015/04/student_achievement_in_us_hist_ht $\mathrm{ml}$

Carrington, B., \& Short, G. (1997). Holocaust education, anti-racism and citizenship. Educational Review, 47, 271-282. doi:https://doi.org/10.1080/0013191970490306 
Cowan, P., \& Maitles, H. (2005). Values and attitudes-positive and negative: A study of the impact of teaching the Holocaust on citizenship among Scottish 11-12 year olds. Scottish Educational Review, 37(2).

Cowan, P., \& Maitles, H. (2007). Does addressing prejudice and discrimination through Holocaust education produce better citizens? Educational Review, 59(2), 115-130.

Crowe, D. M. (1970). The Holocaust: Roots, History, and Aftermath. New York: Routledge.

Doering, Z. D., \& Pekarik, A. J. (1996). Assessment of informal education in Holocaust

museums. Washington, DC: Smithsonian Institute, Institutional Studies Office. Retrieved from https://repository.si.edu/bitstream/handle/10088/17201/opanda_96-2B-

Education.pdf? sequence $=1 \&$ is Allowed $=\mathrm{y}$

Downey, S. (2000). Findings and implications from an evaluation of school programs at the United States Holocaust Memorial Museum. Visitor Studies Today, 3(2), 13-16.

Dwork, D., \& Van Pelt, R. J. (2002). Holocaust: A History. New York: Norton.

Farkas, S., \& Duffett, A. M. (2010). High school, civics, and citizenship: What social studies teachers think and do. American Enterprise Institute. Retrieved from https://www.aei.org/wp-content/uploads/2014/09/High-Schools-Civics-Citizenship-FullReport.pdf

Foster, S. J., Pettigrew, A., Pearce, A. R., Hale, R., Burgess, A., Salmons, P., \& Lenga, R. (2016). What do students know and understand about the Holocaust? Evidence from English secondary schools. Centre for Holocaust Education, Institute of Education, University College London, London, U.K. Retrieved from http://discovery.ucl.ac.uk/1475816/

Gibson, J. L., \& Bingham, R. D. (1982). On the conceptualization and measurement of political tolerance. The American Political Science Review, 76(3), 603-620. 
Gilbert, M. (1987). The Holocaust: A History of the Jews of Europe During the Second World War. New York: Henry Holt and Company, LLC.

Graham, J., Haidt, J., \& Nosek, B. A. (2009). Liberals and conservatives rely on different sets of moral foundations. Journal of Personality and Social Psychology, 96(5).

Greene, J. P., Erickson, H. H., Watson, A. R., \& Beck, M. I. (2018). The play's the thing:

Experimentally examining the social and cognitive effects of school field trips to live theater performances. Educational Researcher, 47(4), 246-254.

Greene, J. P., Kisida, B., \& Bowen, D. H. (2014). The educational value of field trips. Education Next, 14(1), 78-86.

Gutmann, A. (1987). Democratic education. Princeton, New Jersey: Princeton University Press.

Hess, F. M., Schmitt, G. J., Miller, C., \& Schuette, J. M. (2010, September). Foreword to High schools, civics, and citizenship: What social studies teachers think and do. American Enterprise Institute. Retrieved from American Enterprise Institute: https://www.aei.org/wp-content/uploads/2014/09/High-Schools-Civics-Citizenship-FullReport.pdf

Hirsch, E. D. (2009). The making of Americans. New Haven, Connecticut: Yale University Press. Jennings, L. B. (2010). Challenges and possibilities of Holocaust education and critical citizenship: An ethnographic study of a fifth-grade bilingual class revisited. Prospects, $40,35-56$.

Katz, B. (2018, April 12). Americans believe Holocaust education is important, but survey finds gaps in their knowledge. Smithsonian Institution. Retrieved from https:/www.smithsonianmag.com/smart-news/americans-believe-holocaust-educationimportant-have-gaps-their-knowledge-holocaust-history-180968783/ 
Kisida, B., Bowen, D. H., \& Greene, J. P. (2016). Measuring critical thinking: Results from an art museum field trip experiment. Journal of Research on Educational Effectiveness, 9(1), 171-187. doi:https://doi.org/10.1080/19345747.2015.1086915

Landau, R. (1992). The Nazi Holocaust. London, U. K.: I. B. Tauris \& Company Limited. Levinson, M. (2012). No citizen left behind. Cambridge, Massachusetts: Harvard University Press.

Lindquist, D. H. (2006). Guidelines for teaching the Holocaust: Avoiding common pedagogical errors. The Social Studies, 97(5), 215-221. doi:10.3200/TSSS.97.5.215-221

Lipstadt, D. E. (1995). Not facing history. The New Republic, 212(10), 26-29.

Longerich, P. (2010). Holocaust: The Nazi Persecution and Murder of the Jews. Oxford: Oxford University Press.

Marcus, A. (2018, May 23). Why we need to rethink how to teach the Holocaust. The Associated Press. Retrieved from https://wtop.com/national/2018/05/why-we-need-to-rethink-howto-teach-the-holocaust/

Peterson, P. E. (2010). Saving schools: From Horace Mann to virtual learning. Cambridge, Massachusetts: The Belknap Press of Harvard University Press.

Riley, K., \& Totten, S. (2002). Understanding matters: Holocaust curricula and the social studies classroom. Theory \& Research in Social Education, 30(4), 541-562.

Russell, I. W. (2005). Teaching about the Holocaust: A resource guide. The Social Studies, 96(2), 93-96.

Schoen Consulting. (2018). Holocaust knowledge awareness study executive summary. Retrieved from http://www.claimscon.org/wp-content/uploads/2018/04/HolocaustKnowledge-Awareness-Study_Executive-Summary-2018.pdf 
Schweber, S. (2003). Simulating survival. Curriculum Inquiry, 9(2), 139-188.

Shapiro, S., \& Brown, C. (2018, February 21). The state of civics education. Retrieved from Center for American Progress: https://www.americanprogress.org/issues/education-k12/reports/2018/02/21/446857/state-civics-education/

Shiman, D. A., \& Fernekes, W. R. (1999). The Holocaust, human rights, and democratic citizenship education. The Social Studies, 90(2), 53-62. doi:10.1080/00377999909602391

Slaby, R. G., Wilson-Brewer, R., \& Dash, K. (1994). Aggressors, victims, and bystanders: Thinking and acting to prevent violence. Newton, MA: Education Development Center.

Spreng, R. N., McKinnon, M. C., Mar, R. A., \& Levine, B. (2009). The Toronto empathy questionnaire: Scale development and initial validation of a factor-analytic solution to multiple empathy measures. Journal of Personality Assessment, 91, 62-71.

Starratt, G. K., Fredotovic, I., Goodletty, S., \& Starratt, C. (2017). Holocaust knowledge and Holocaust education experiences predict citizenship values among U.S. adults. Journal of Moral Education, 1-18.

Tec, N. (1995). Altruism and the Holocaust. Social Education, 59, 348-353.

Totten, S. (2012). Holocaust education. In S. Totten, \& J. E. Pederson (Eds.), Educating about social issues in the 20th and 21st centuries: A critical annotated bibliography (pp. 223250). Charlotte, North Carolina: Information Age Publishing.

Totten, S. (2013). Richard E. Gross: Addressing controversial issues in the classroom. In S. Totten, \& J. E. Pederson (Eds.), Educating about social issues in the 20th and 21st centuries: A critical annotated bibliography (Vol. 2, pp. 45-56). Charlotte, NC: Information Age Publishing, Inc. 
Weinstein, M., Whitesell, E. R., \& Schwartz, A. E. (2014). Museums, zoos, and gardens: How formal-informal partnerships can impact urban students' performance in science. Evaluation Review, 38(6), 514-545.

West, M. R. (2007). Testing, learning, and teaching: The effects of test-based accountability on student achievement and instructional time in core academic subjects. In C. E. Finn, \& D. Ravitch (Eds.), Beyond the basics: Achieving a liberal education for all children (pp. 4561). Washington, DC: Fordham Institute.

Whitesell, E. R. (2016). A day at the museum: The impact of field trips on middle school science achievement. Journal of Research in Science Teaching, 53(7), 1036-1054.

Wieser, P. (2001). Instruction issues/strategies in teaching the Holocaust. In S. Totten, \& S. Feinberg, Teaching and studying the Holocaust (pp. 62-80). Boston, MA: Allyn \& Bacon.

Ziv, S. (2017, May 1). Two new efforts launched to require Holocaust education nationwide, one triggered by Spicer. Newsweek. Retrieved from https://www.newsweek.com/two-newefforts-launched-require-holocaust-education-nationwide-one-triggered-592671 


\section{Appendix}

\section{Table A1}

Breakout sessions and speakers at Holocaust conference

\begin{tabular}{|c|c|c|}
\hline Speaker & Topic & Institution \\
\hline Chad Austin, JD & $\begin{array}{l}\text { Undeniable Proofs - The Role of } \\
\text { Law in Creating a Record for } \\
\text { History to Judge }\end{array}$ & $\begin{array}{l}\text { Professor, United States Air Force } \\
\text { Academy, CO }\end{array}$ \\
\hline Dr. Andrew Buchanan, PhD & $\begin{array}{l}\text { The Nazi Concentration Camp } \\
\text { (Konzentrationslager KZ) System: } \\
\text { Why did the KZ system emerge and } \\
\text { how did the Nazis use it to } \\
\text { implement systematic, bureaucratic, } \\
\text { state-sponsored persecution and } \\
\text { mass murder? }\end{array}$ & $\begin{array}{l}\text { Teacher, Randolph High School, } \\
\text { Randolph, NJ } \\
\text { PhD International Relations, } \\
\text { University of St. Andrews }\end{array}$ \\
\hline Sol Factor & $\begin{array}{l}\text { When Lady Liberty Snuffed out } \\
\text { Her Welcome Lamp: The Reasons } \\
\text { Behind America's Actions During } \\
\text { the Holocaust }\end{array}$ & $\begin{array}{l}\text { Kent State University, Kent, OH } \\
\text { Mandel Fellow, United States } \\
\text { Holocaust Memorial Museum, } \\
\text { Washington, DC }\end{array}$ \\
\hline Jacqueline Littlefield & $\begin{array}{l}\text { The American Public and the } \\
\text { Holocaust - What Did They Know? }\end{array}$ & $\begin{array}{l}\text { Education Coordinator, Holocaust } \\
\text { and Human Rights Center of } \\
\text { Maine, Augusta, ME }\end{array}$ \\
\hline Dr. Dorian Stuber, $\mathrm{PhD}$ & One Week in Holocaust Diaries & $\begin{array}{l}\text { Associate Professor, Hendrix } \\
\text { College, Conway, AR } \\
\text { PhD, Cornell University }\end{array}$ \\
\hline Lance Jones & $\begin{array}{l}\text { What They Knew and When They } \\
\text { Knew It: Knowledge of the } \\
\text { Holocaust on the German } \\
\text { Homefront During World War II }\end{array}$ & $\begin{array}{l}\text { Adjunct Instructor, Casper College, } \\
\text { Casper, WY } \\
\text { United States } \\
\text { Museum Teacher Fellow, United } \\
\text { States Holocaust Memorial } \\
\text { Museum, Washington, DC }\end{array}$ \\
\hline Laura Pritchard Dobrin & $\begin{array}{l}\text { What Germans Knew about the } \\
\text { Holocaust }\end{array}$ & $\begin{array}{l}\text { Teacher Fellow, United States } \\
\text { Holocaust Memorial Museum, } \\
\text { Washington, DC } \\
\text { Master Teacher, Shoah Foundation, } \\
\text { University of Southern California, } \\
\text { Los Angeles, CA }\end{array}$ \\
\hline
\end{tabular}


Tables

Table 1

Baseline characteristics on administrative demographic data

\begin{tabular}{|c|c|c|c|c|}
\hline & Treat & Control & $\begin{array}{c}\text { Difference } \\
(1)-(2)\end{array}$ & $p$-value \\
\hline & $(1)$ & $(2)$ & $(3)$ & $(4)$ \\
\hline \multirow[t]{2}{*}{ Grade } & 11.02 & 11.13 & -0.11 & 0.594 \\
\hline & $(1.08)$ & $(1.01)$ & $(0.20)$ & \\
\hline \multicolumn{5}{|l|}{ Race } \\
\hline \multirow{2}{*}{ White } & 0.68 & 0.75 & -0.07 & 0.463 \\
\hline & $(0.47)$ & $(0.44)$ & $(0.09)$ & \\
\hline \multirow[t]{2}{*}{ Minority } & 0.32 & 0.25 & 0.07 & 0.463 \\
\hline & $(0.47)$ & $(0.44)$ & $(0.09)$ & \\
\hline \multirow[t]{2}{*}{ Hispanic } & 0.18 & 0.11 & 0.07 & 0.304 \\
\hline & $(0.39)$ & $(0.31)$ & $(0.07)$ & \\
\hline \multirow[t]{2}{*}{ Black } & 0.06 & 0.04 & 0.02 & 0.574 \\
\hline & $(0.24)$ & $(0.19)$ & $(0.04)$ & \\
\hline \multirow[t]{2}{*}{ Asian } & 0.02 & 0.05 & -0.03 & 0.361 \\
\hline & $(0.14)$ & $(0.23)$ & $(0.04)$ & \\
\hline \multirow[t]{2}{*}{ Two or more races } & 0.06 & 0.05 & 0.01 & 0.905 \\
\hline & $(0.24)$ & $(0.23)$ & $(0.05)$ & \\
\hline \multirow[t]{2}{*}{ Female } & 0.58 & 0.58 & 0.00 & 0.985 \\
\hline & $(0.50)$ & $(0.50)$ & $(0.10)$ & \\
\hline \multirow[t]{2}{*}{ Age (in days) } & $6,173.24$ & $6,171.20$ & 2.04 & 0.979 \\
\hline & $(414.78)$ & $(390.87)$ & $(78.63)$ & \\
\hline \multirow[t]{2}{*}{ School 1} & 0.72 & 0.73 & -0.01 & 0.934 \\
\hline & $(0.45)$ & $(0.45)$ & $(0.09)$ & \\
\hline$n$ & 50 & 55 & & \\
\hline
\end{tabular}

Notes. Treatment and control groups demonstrated balance on all administrative demographic characteristics. 
Table 2

Baseline characteristics of outcomes measures

\begin{tabular}{|c|c|c|c|c|}
\hline & Treat & Control & $\begin{array}{c}\text { Difference } \\
(1)-(2)\end{array}$ & $p$-value \\
\hline & (1) & (2) & & (4) \\
\hline \multirow[t]{2}{*}{ Upstander } & 3.29 & 3.25 & 0.04 & 0.695 \\
\hline & $(0.41)$ & $(0.50)$ & (0.09) & \\
\hline \multirow[t]{2}{*}{ Civil disobedience } & 2.77 & 2.69 & 0.08 & 0.479 \\
\hline & $(0.51)$ & $(0.57)$ & $(0.11)$ & \\
\hline \multirow[t]{2}{*}{ Empathy } & 3.69 & 3.71 & -0.02 & 0.836 \\
\hline & $(0.53)$ & $(0.48)$ & $(0.10)$ & \\
\hline \multirow{2}{*}{ Tolerance } & 3.50 & 3.54 & -0.04 & 0.671 \\
\hline & $(0.47)$ & $(0.47)$ & (0.09) & \\
\hline \multirow[t]{2}{*}{ Knowledge } & 7.28 & 7.24 & 0.04 & 0.914 \\
\hline & $(1.95)$ & $(2.14)$ & $(0.40)$ & \\
\hline$n$ & 50 & 53 & & \\
\hline
\end{tabular}


Table 3

Baseline measures of exposure to Holocaust instruction, books, and movies

\begin{tabular}{|c|c|c|c|c|}
\hline & Treat & Control & $\begin{array}{c}\text { Difference } \\
(1)-(2)\end{array}$ & $p$-value \\
\hline & $(1)$ & $(2)$ & (3) & $(4)$ \\
\hline \multirow[t]{2}{*}{ Exposure } & 0.32 & 0.33 & -0.01 & 0.886 \\
\hline & $(0.23)$ & $(0.20)$ & $(0.04)$ & \\
\hline \multirow[t]{2}{*}{ The Boy in the Striped Pajamas } & 0.56 & 0.60 & -0.04 & 0.656 \\
\hline & $(0.50)$ & $(0.49)$ & $(0.10)$ & \\
\hline \multirow{2}{*}{ The Chosen } & 0.06 & 0.02 & 0.04 & 0.285 \\
\hline & $(0.24)$ & $(0.14)$ & $(0.04)$ & \\
\hline \multirow[t]{2}{*}{ The Diary of Anne Frank } & 0.64 & 0.70 & -0.06 & 0.535 \\
\hline & $(0.48)$ & $(0.46)$ & $(0.09)$ & \\
\hline \multirow[t]{2}{*}{ Night } & 0.42 & 0.25 & $0.17 *$ & 0.060 \\
\hline & $(0.50)$ & $(0.43)$ & $(0.09)$ & \\
\hline \multirow[t]{2}{*}{ Number the Stars } & 0.22 & 0.25 & -0.03 & 0.764 \\
\hline & $(0.42)$ & $(0.43)$ & $(0.08)$ & \\
\hline \multirow[t]{2}{*}{ Maus } & 0.04 & 0.11 & -0.07 & 0.169 \\
\hline & $(0.20)$ & $(0.32)$ & $(0.05)$ & \\
\hline \multirow[t]{2}{*}{ Schindler's List } & 0.20 & 0.19 & 0.01 & 0.886 \\
\hline & $(0.40)$ & $(0.39)$ & $(0.08)$ & \\
\hline \multirow[t]{2}{*}{ Life is Beautiful } & 0.14 & 0.28 & $-0.14 *$ & 0.078 \\
\hline & $(0.35)$ & $(0.45)$ & $(0.08)$ & \\
\hline \multirow[t]{2}{*}{ Number of courses with instruction on the Holocaust } & 8.46 & 5.00 & 3.46 & 0.151 \\
\hline & $(16.02)$ & $(6.62)$ & $(2.39)$ & \\
\hline$n$ & 50 & 53 & & \\
\hline
\end{tabular}

Notes. ${ }^{*} p<0.10$. Treatment and control groups demonstrated balance on all measures of pre-treatment exposure to Holocaust education, with two exceptions. Treatment group students were 17 percentage points more likely to have read Night by Elie

Wiesel, and control group students were 14 percentage points more likely to have seen the film Life is Beautiful. 
Table 4

Baseline measures of interest in Holocaust education

\begin{tabular}{|c|c|c|c|c|}
\hline & Treat & Control & $\begin{array}{c}\text { Difference } \\
(1)-(2)\end{array}$ & $p$-value \\
\hline Interest & $\begin{array}{c}3.34 \\
(0.63)\end{array}$ & $\begin{array}{c}3.45 \\
(0.60)\end{array}$ & $\begin{array}{l}-0.11 \\
(0.12)\end{array}$ & 0.356 \\
\hline I am interested in learning about history. & $\begin{array}{c}3.36 \\
(0.78)\end{array}$ & $\begin{array}{c}3.51 \\
(0.72)\end{array}$ & $\begin{array}{l}-0.15 \\
(0.15)\end{array}$ & 0.314 \\
\hline I am interested in learning more about the Holocaust. & $\begin{array}{c}3.38 \\
(0.75)\end{array}$ & $\begin{array}{c}3.53 \\
(0.72)\end{array}$ & $\begin{array}{l}-0.15 \\
(0.15)\end{array}$ & 0.310 \\
\hline Learning about the Holocaust can help prevent further violence. & $\begin{array}{c}3.36 \\
(0.78)\end{array}$ & $\begin{array}{c}3.36 \\
(0.81)\end{array}$ & $\begin{array}{c}0.00 \\
(0.16)\end{array}$ & 0.992 \\
\hline I am interested in attending the Arkansas Holocaust Education Conference. & $\begin{array}{c}3.24 \\
(0.80)\end{array}$ & $\begin{array}{c}3.40 \\
(0.74)\end{array}$ & $\begin{array}{l}-0.16 \\
(0.15)\end{array}$ & 0.306 \\
\hline$n$ & 50 & 53 & & \\
\hline
\end{tabular}

Notes. Treatment and control groups demonstrate balance on measures of interest in Holocaust education at baseline. 
Table 5

Cronbach's alpha for post-treatment survey measures

\begin{tabular}{|c|c|c|c|c|c|c|}
\hline & \multicolumn{2}{|c|}{ Pre-Treatment } & \multicolumn{2}{|c|}{ Post-Treatment } & \multirow{2}{*}{$\alpha$} & \multirow{2}{*}{ Range } \\
\hline & $\mu$ & $\sigma$ & $\mu$ & $\sigma$ & & \\
\hline & $(1)$ & $(2)$ & (3) & $(4)$ & $(5)$ & $(6)$ \\
\hline Upstander & 3.27 & 0.45 & 3.30 & 0.50 & 0.79 & 1 (Very unlikely) to 4 (Very likely) \\
\hline Civil Disobedience & 2.73 & 0.54 & 2.64 & 0.58 & 0.85 & 1 (Definitely obey) to 4 (Definitely disobey) \\
\hline Empathy & 3.70 & 0.50 & 3.66 & 0.65 & 0.92 & 1 (Almost never) to 5 (Almost all the time) \\
\hline Tolerance & 3.52 & 0.47 & 3.47 & 0.52 & 0.93 & 1 (Very uncomfortable) to 4 (Very comfortable) \\
\hline Knowledge & 7.40 & 1.79 & 7.46 & 1.96 & & 0 (Incorrect) to 1 (Correct) on 10 questions \\
\hline
\end{tabular}

Notes. Cronbach's alphas reported from post-treatment surveys. Cronbach's alphas from pre-treatment surveys available upon request. 
Table 6

Survey measures and sample items

\begin{tabular}{|c|c|c|c|c|c|}
\hline \multirow{2}{*}{ Outcome } & \multirow{2}{*}{ Source } & \multirow{2}{*}{ Sample Item } & \multicolumn{2}{|c|}{ Range } & \multirow{2}{*}{$\begin{array}{l}\text { Number } \\
\text { of items }\end{array}$} \\
\hline & & & Min & Max & \\
\hline (1) & $(2)$ & (3) & $(4)$ & $(5)$ & $(6)$ \\
\hline Upstander & $\begin{array}{l}\text { Slaby, Wilson-Brewer, \& } \\
\text { DeVos (1994); Banyard et al. } \\
\text { (2002); Bowen \& Kisida } \\
\text { (2017) }\end{array}$ & $\begin{array}{l}\text { On a scale of } 1-4 \text {, how likely are you } \\
\text { to speak up for someone, even if it } \\
\text { will result in ridicule? }\end{array}$ & 1 & 4 & 4 \\
\hline Civil Disobedience & $\begin{array}{l}\text { Graham, Haidt, \& Nosek } \\
\text { (2009); Bowen \& Kisida } \\
\text { (2017) }\end{array}$ & $\begin{array}{l}\text { If a law existed that you believed to } \\
\text { be unjust or immoral, would you } \\
\text { obey or disobey the law if it resulted } \\
\text { in arrest, imprisonment, or criminal } \\
\text { charges? }\end{array}$ & 1 & 4 & 11 \\
\hline Empathy & $\begin{array}{l}\text { Spreng et al. (2009); Bowen \& } \\
\text { Kisida (2017) }\end{array}$ & $\begin{array}{l}\text { On a scale of 1-4, how strongly do } \\
\text { you agree with the following } \\
\text { statement?: It upsets me to see } \\
\text { someone being treated } \\
\text { disrespectfully. }\end{array}$ & 1 & 5 & 12 \\
\hline Tolerance & $\begin{array}{l}\text { Gibson \& Bingham (1982); } \\
\text { Gallup's Religious Tolerance } \\
\text { Index for Teens; Bowen \& } \\
\text { Kisida (2017) }\end{array}$ & $\begin{array}{l}\text { On a scale of } 1-4 \text {, how comfortable } \\
\text { would you be living next door to } \\
\text { someone of a different religious } \\
\text { faith? }\end{array}$ & 1 & 4 & 17 \\
\hline Knowledge & & $\begin{array}{l}\text { Which of the following was NOT a } \\
\text { targeted victim group during the } \\
\text { Holocaust? }\end{array}$ & 0 & 1 & 10 \\
\hline
\end{tabular}


Table 7

Impact estimates of being assigned to attend the conference

\begin{tabular}{|c|c|c|c|}
\hline & Simple & Demographics & Preferred \\
\hline & (1) & (2) & (3) \\
\hline \multirow[t]{2}{*}{ Upstander } & 0.30 & 0.31 & $0.27 *$ \\
\hline & $(0.19)$ & $(0.19)$ & $(0.15)$ \\
\hline \multirow[t]{2}{*}{ Civil Disobedience } & 0.20 & 0.19 & 0.10 \\
\hline & $(0.17)$ & $(0.17)$ & $(0.15)$ \\
\hline \multirow[t]{2}{*}{ Empathy } & 0.22 & 0.23 & 0.22 \\
\hline & $(0.19)$ & $(0.19)$ & $(0.14)$ \\
\hline \multirow[t]{2}{*}{ Tolerance } & 0.08 & 0.10 & 0.13 \\
\hline & $(0.22)$ & $(0.21)$ & (0.19) \\
\hline \multirow[t]{2}{*}{ Knowledge } & 0.13 & 0.13 & $0.26^{*}$ \\
\hline & $(0.16)$ & $(0.16)$ & $(0.13)$ \\
\hline \multicolumn{4}{|l|}{ Controls } \\
\hline School fixed effect & $\mathrm{X}$ & $\mathrm{X}$ & $\mathrm{X}$ \\
\hline Demographics & & $\mathrm{X}$ & $\mathrm{X}$ \\
\hline Baseline & & & $\mathrm{X}$ \\
\hline$n$ & 102 & 102 & 100 \\
\hline
\end{tabular}

Notes. Robust standard errors in parentheses, accounting for correlated errors within class period. $* p<0.10$. 
Table 8

Average baseline measures by subgroup

\begin{tabular}{|c|c|c|c|c|c|}
\hline & $\frac{\text { Overall }}{(1)}$ & $\frac{\text { White }}{(2)}$ & $\frac{\text { Minority }}{(3)}$ & $\frac{\text { Male }}{(4)}$ & $\frac{\text { Female }}{(5)}$ \\
\hline$n$ & 105 & 75 & 30 & 44 & 61 \\
\hline Knowledge & 7.40 & 7.45 & 7.27 & 7.53 & 7.30 \\
\hline Upstander & 3.27 & 3.28 & 3.26 & 3.21 & 3.32 \\
\hline Civil Disobedience & 2.73 & 2.72 & 2.75 & 2.66 & 2.78 \\
\hline Empathy & 3.70 & 3.76 & 3.58 & 3.43 & 3.90 \\
\hline Tolerance & 3.52 & 3.56 & 3.43 & 3.41 & 3.60 \\
\hline
\end{tabular}


Table 9

Subgroup analysis

\begin{tabular}{|c|c|c|c|c|c|c|}
\hline & \multicolumn{3}{|c|}{ Racial Analysis } & \multicolumn{3}{|c|}{ Gender Analysis } \\
\hline & White & Minority & $\begin{array}{l}\text { Difference } \\
(1)-(2)\end{array}$ & Male & Female & $\begin{array}{c}\text { Difference } \\
\text { (4) - (5) }\end{array}$ \\
\hline & $(1)$ & (2) & (3) & (4) & (5) & $(6)$ \\
\hline \multicolumn{7}{|l|}{ Outcomes } \\
\hline \multirow[t]{2}{*}{ Upstander } & 0.09 & $0.72 * * *$ & $-0.63 * *$ & 0.27 & 0.27 & 0.00 \\
\hline & $(0.23)$ & $(0.22)$ & $(0.30)$ & $(0.21)$ & $(0.21)$ & $(0.29)$ \\
\hline \multirow[t]{2}{*}{ Civil Disobedience } & 0.00 & 0.33 & -0.33 & 0.13 & 0.07 & -0.06 \\
\hline & $(0.18)$ & $(0.22)$ & $(0.27)$ & $(0.23)$ & $(0.16)$ & $(0.24)$ \\
\hline \multirow[t]{2}{*}{ Empathy } & 0.10 & 0.50 & -0.39 & 0.15 & 0.27 & 0.12 \\
\hline & $(0.13)$ & $(0.36)$ & $(0.39)$ & $(0.28)$ & $(0.18)$ & $(0.37)$ \\
\hline \multirow[t]{2}{*}{ General Tolerance } & 0.17 & 0.05 & 0.12 & 0.12 & 0.15 & 0.03 \\
\hline & $(0.24)$ & $(0.31)$ & $(0.39)$ & $(0.33)$ & $(0.27)$ & $(0.45)$ \\
\hline \multirow[t]{2}{*}{ Knowledge } & 0.18 & $0.48 *$ & -0.30 & -0.03 & 0.46 & 0.49 \\
\hline & $(0.14)$ & $(0.23)$ & $(0.25)$ & $(0.19)$ & $(0.21)$ & $(0.32)$ \\
\hline \multicolumn{7}{|l|}{ Controls } \\
\hline School Fixed Effect & & $\mathrm{X}$ & & & $\mathrm{X}$ & \\
\hline Demographics & & $\mathrm{X}$ & & & $\mathrm{X}$ & \\
\hline Baseline & & $\mathrm{X}$ & & & $X$ & \\
\hline$n$ & & 100 & & & 100 & \\
\hline
\end{tabular}


Table 10

Sensitivity checks

\begin{tabular}{|c|c|c|c|c|c|}
\hline & $\begin{array}{c}\text { Preferred } \\
(1)\end{array}$ & $\begin{array}{c}\text { Knowledge } \\
(2)\end{array}$ & $\frac{\text { Interest }}{(3)}$ & $\begin{array}{c}\text { Exposure } \\
(4)\end{array}$ & $\begin{array}{l}\text { All } \\
(5)\end{array}$ \\
\hline Upstander & $0.27 *$ & $0.29 *$ & $0.29 *$ & $0.27 *$ & $0.30 * *$ \\
\hline SE & $(0.15)$ & $(0.14)$ & $(0.15)$ & $(0.15)$ & $(0.14)$ \\
\hline$p$ & 0.094 & 0.055 & 0.065 & 0.095 & 0.042 \\
\hline Civil Disobedience & 0.10 & 0.10 & 0.09 & 0.10 & 0.09 \\
\hline SE & $(0.15)$ & $(0.15)$ & $(0.14)$ & $(0.15)$ & $(0.14)$ \\
\hline$p$ & 0.525 & 0.521 & 0.540 & 0.523 & 0.544 \\
\hline Empathy & 0.22 & 0.21 & 0.22 & 0.22 & 0.21 \\
\hline SE & $(0.14)$ & $(0.13)$ & $(0.14)$ & $(0.13)$ & $(0.14)$ \\
\hline$p$ & 0.123 & 0.141 & 0.143 & 0.118 & 0.151 \\
\hline Tolerance & 0.13 & 0.16 & 0.15 & 0.13 & 0.16 \\
\hline SE & $(0.19)$ & $(0.18)$ & $(0.18)$ & $(0.20)$ & $(0.18)$ \\
\hline$p$ & 0.490 & 0.400 & 0.418 & 0.500 & 0.382 \\
\hline Knowledge & $0.26^{*}$ & & $0.28 * *$ & $0.27 *$ & $0.28 * *$ \\
\hline SE & $(0.13)$ & & $(0.12)$ & $(0.13)$ & $(0.12)$ \\
\hline$p$ & 0.058 & & 0.036 & 0.055 & 0.035 \\
\hline \multicolumn{6}{|l|}{ Controls } \\
\hline School Fixed Effect & $\mathrm{X}$ & $\mathrm{X}$ & $\mathrm{X}$ & $\mathrm{X}$ & $\mathrm{X}$ \\
\hline Demographics & $\mathrm{X}$ & $\mathrm{X}$ & $\mathrm{X}$ & $\mathrm{X}$ & $\mathrm{X}$ \\
\hline Baseline Outcome & $\mathrm{X}$ & $X$ & $\mathrm{X}$ & $X$ & $\mathrm{X}$ \\
\hline Baseline Knowledge & & $X$ & & & $\mathrm{X}$ \\
\hline Baseline Interest & & & $\mathrm{X}$ & & $\mathrm{X}$ \\
\hline Baseline Exposure & & & & $\mathrm{X}$ & $\mathrm{X}$ \\
\hline
\end{tabular}

Notes. Robust standard errors in parentheses, accounting for correlated errors within class period. ${ }^{* *} p<0.05,{ }^{*} p<0.10$. 
Table 11

Impact estimates of being assigned to attend the conference on knowledge

\begin{tabular}{|c|c|c|c|c|c|}
\hline & & \multicolumn{3}{|c|}{ T-Tests } & \multirow{3}{*}{$\begin{array}{c}\begin{array}{c}\text { Preferred } \\
\text { Model }\end{array} \\
\beta \text { treat } \\
(4)\end{array}$} \\
\hline & & Treat & Control & \multirow{2}{*}{$\begin{array}{l}\text { Difference } \\
\frac{(1)-(2)}{(3)}\end{array}$} & \\
\hline & & (1) & $(2)$ & & \\
\hline Q1. & What is anti-Semitism? & $\begin{array}{c}0.90 \\
(0.04)\end{array}$ & $\begin{array}{c}0.91 \\
(0.04)\end{array}$ & $\begin{array}{l}-0.01 \\
(0.06)\end{array}$ & $\begin{array}{c}0.01 \\
(0.06)\end{array}$ \\
\hline Q2. & $\begin{array}{l}\text { What is the name of Hitler's manifesto in which he outlines his } \\
\text { ideology and plans? }\end{array}$ & $\begin{array}{c}0.84 \\
(0.05)\end{array}$ & $\begin{array}{c}0.89 \\
(0.04)\end{array}$ & $\begin{array}{l}-0.05 \\
(0.07)\end{array}$ & $\begin{array}{l}-0.02 \\
(0.05)\end{array}$ \\
\hline Q3. & $\begin{array}{l}\text { Which of the following was NOT a targeted victim group during the } \\
\text { Holocaust? }\end{array}$ & $\begin{array}{c}0.92 \\
(0.04)\end{array}$ & $\begin{array}{c}0.85 \\
(0.05)\end{array}$ & $\begin{array}{c}0.07 \\
(0.06)\end{array}$ & $\begin{array}{c}0.09 \\
(0.06)\end{array}$ \\
\hline Q4. & $\begin{array}{l}\text { Which of the following statements is true about the growth of anti- } \\
\text { Jewish policies after World War I and before the Holocaust? }\end{array}$ & $\begin{array}{c}0.69 \\
(0.07)\end{array}$ & $\begin{array}{l}0.70 \\
(0.06)\end{array}$ & $\begin{array}{c}0.00 \\
(0.09)\end{array}$ & $\begin{array}{c}0.03 \\
(0.08)\end{array}$ \\
\hline Q5. & What was Kristallnacht? & $\begin{array}{c}0.67 \\
(0.07)\end{array}$ & $\begin{array}{c}0.58 \\
(0.07)\end{array}$ & $\begin{array}{c}0.09 \\
(0.10)\end{array}$ & $\begin{array}{c}0.10 \\
(0.08)\end{array}$ \\
\hline Q6. & What country was declared as a homeland for Jews after WWII? & $\begin{array}{c}0.69 \\
(0.07)\end{array}$ & $\begin{array}{c}0.64 \\
(0.07)\end{array}$ & $\begin{array}{c}0.05 \\
(0.09)\end{array}$ & $\begin{array}{c}0.07 \\
(0.09)\end{array}$ \\
\hline Q7. & $\begin{array}{l}\text { How did many Nazi officers attempt to defend their actions during the } \\
\text { Holocaust at the Nuremberg Trials? }\end{array}$ & $\begin{array}{c}0.67 \\
(0.07)\end{array}$ & $\begin{array}{c}0.74 \\
(0.06)\end{array}$ & $\begin{array}{l}-0.06 \\
(0.09)\end{array}$ & $\begin{array}{l}-0.03 \\
(0.08)\end{array}$ \\
\hline Q8. & How many Jews do historians estimate were killed in the Holocaust? & $\begin{array}{c}0.76 \\
(0.06)\end{array}$ & $\begin{array}{c}0.83 \\
(0.05)\end{array}$ & $\begin{array}{l}-0.08 \\
(0.08)\end{array}$ & $\begin{array}{l}-0.04 \\
(0.07)\end{array}$ \\
\hline Q9. & T/F: The Holocaust was the cause of World War II. & $\begin{array}{c}0.73 \\
(0.06)\end{array}$ & $\begin{array}{c}0.70 \\
(0.06)\end{array}$ & $\begin{array}{c}0.04 \\
(0.09)\end{array}$ & $\begin{array}{c}0.07 \\
(0.07)\end{array}$ \\
\hline Q10. & $\begin{array}{l}\text { T/F: Only Hitler and high-ranking Nazi officials really knew about and } \\
\text { carried out the Holocaust. }\end{array}$ & $\begin{array}{c}0.71 \\
(0.07)\end{array}$ & $\begin{array}{c}0.51 \\
(0.07)\end{array}$ & $\begin{array}{l}0.20^{* *} \\
(0.10)\end{array}$ & $\begin{array}{c}0.24 * * * \\
(0.06)\end{array}$ \\
\hline & Overall knowledge & $\begin{array}{c}7.59 \\
(0.27)\end{array}$ & $\begin{array}{c}7.34 \\
(0.28)\end{array}$ & $\begin{array}{c}0.25 \\
(0.39)\end{array}$ & $\begin{array}{l}0.26^{*} \\
(0.13)\end{array}$ \\
\hline
\end{tabular}

Notes. Standard errors reported in parentheses. Estimates in Column 4 capture the effect of being assigned to attend the conference in our preferred model, which accounts for clustering within class period. $* * * p<0.01, * * p<0.05, * p<0.10$. The difference on Q4. is -0.004 . 


\section{Figures}

Fig. 1

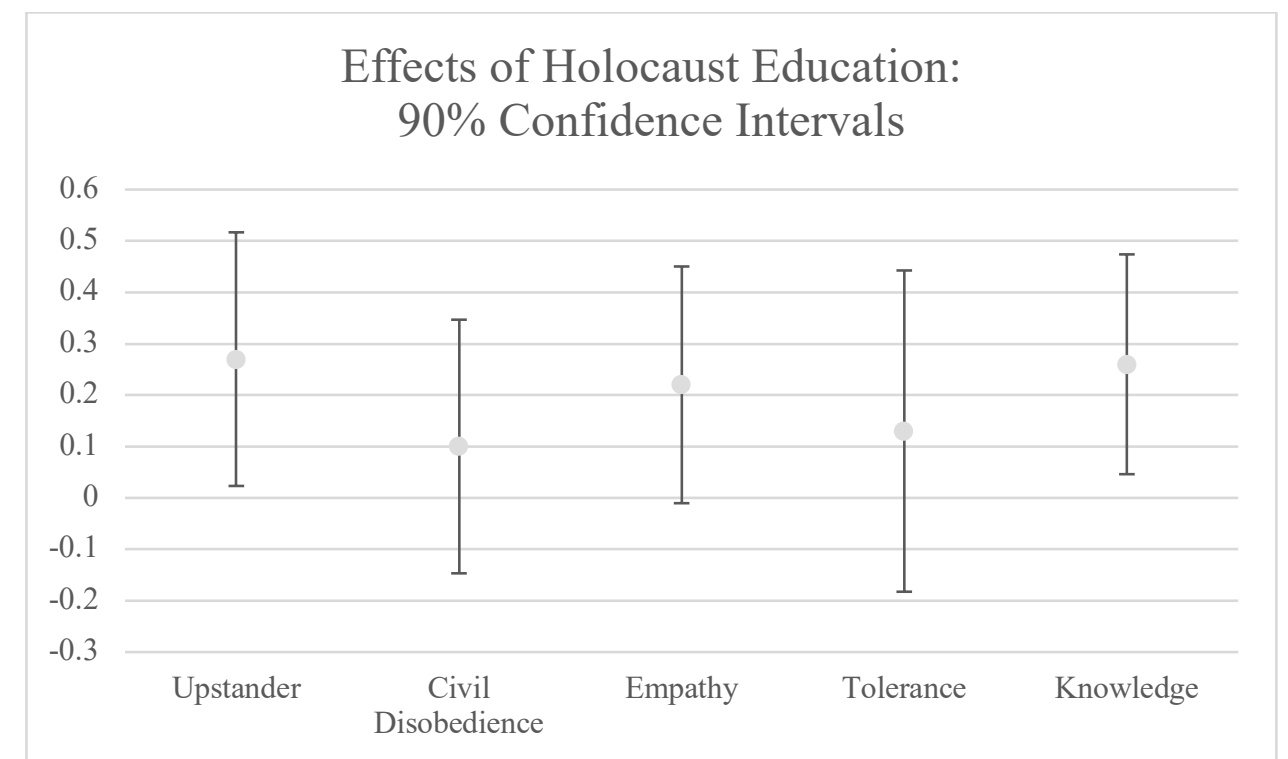

Notes. Estimated effects on upstander and knowledge are both statistically significant at the $90 \%$ confidence level.

Fig. 2

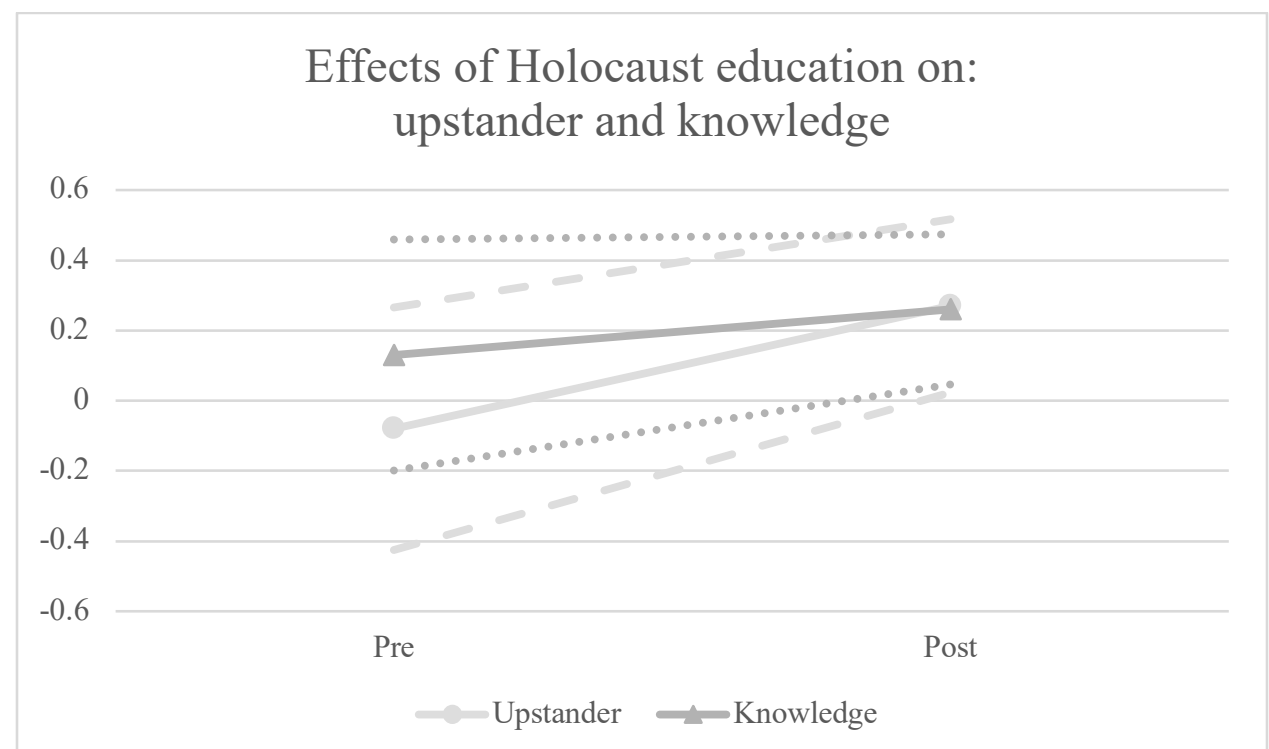

Notes. Dashed lines represent $90 \%$ confidence intervals, with short dashes in gray around knowledge and long dashes in black around upstander. 
Fig. 3

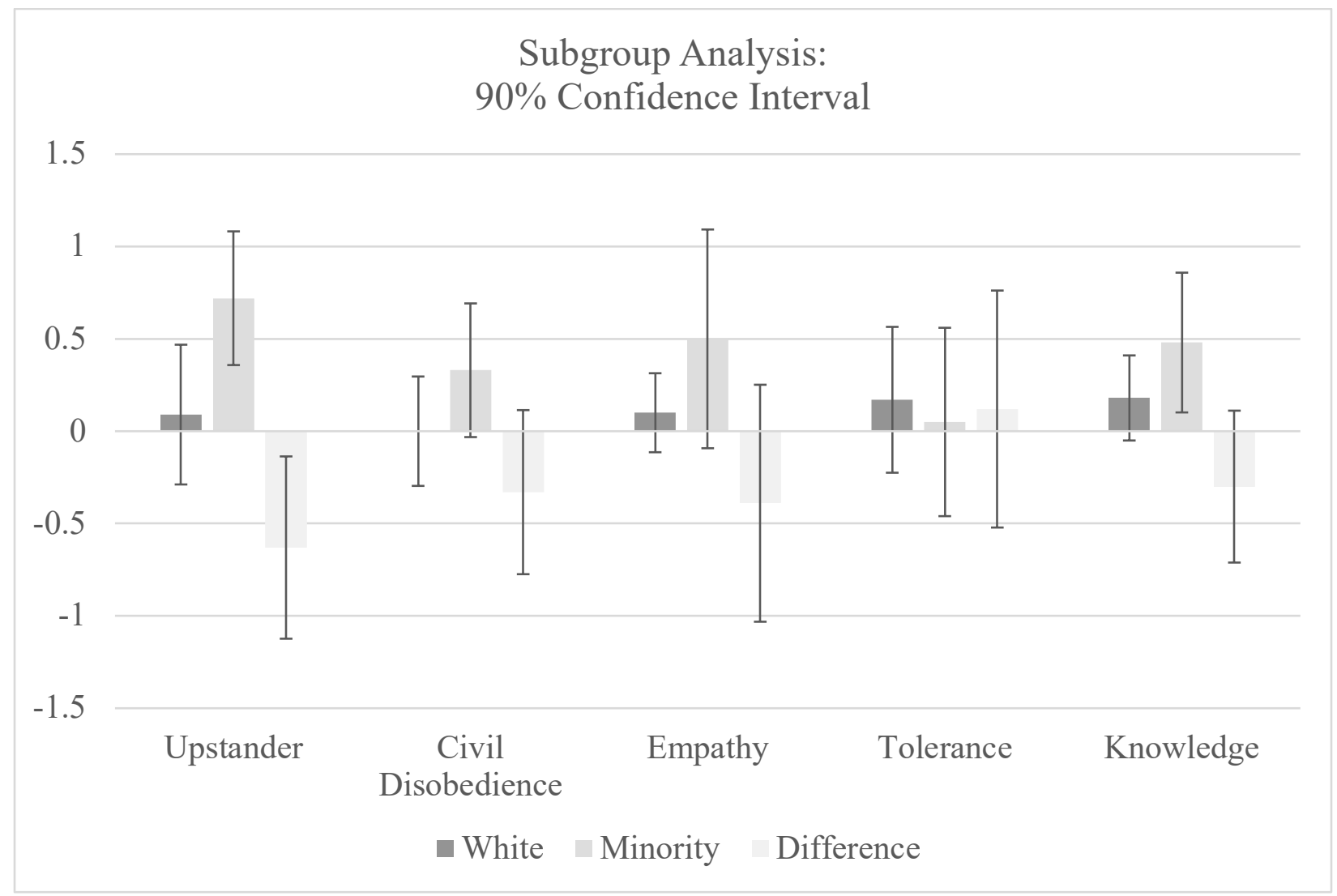

Notes. Effect estimate on upstander for minority students significant at the $99 \%$ confidence level. Effect estimate for the interaction term, capturing the difference in estimated effects on upstander for white and minority students, significant at the $95 \%$ confidence level. Effect estimate on knowledge for minority students significant at the $90 \%$ confidence level. 